\title{
ПОЛУЧЕНИЕ И АНАЛИЗ ПОЛИКЛОНАЛЬНЫХ АНТИТЕЛ К РЕКОМБИНАНТНОМУ ТРАНСКРИПЦИОННОМУ ФАКТОРУ SОХ2
}

\author{
А.Е. Секенова ${ }^{1,2}$, М.Ж. Балтабекова ${ }^{1}$, Б.Б. Хасенов ${ }^{1}$ В.Б. Огай ${ }^{1}$ \\ ${ }^{1}$ РГП «Национальный центр биотехнологии» КН МОН РК, г. Астана \\ 2 Евразийский национальный университет им. Л.Н. Гумилева, г. Астана \\ a.sekenova@mail.ru
}

Транскрипционный фактор Sox2, который экспрессируется в эмбриональных стволовых клетках, играет важную роль в самообновлении и поддержании плюрипотентности эмбриональных и индуцированных плюрипотентных стволовых клеток. В данном исследовании методом плазмидной экспрессии бактериального штамма Rosetta pLysS(DE3), несущего генетическую конструкцию pET28a/Sox2, был наработан рекомбинантный транскрипционный фактор Sox2. Целевой ген Sox2 был встроен под контроль промотора РНК полимеразы Т7 и содержал гистидиновую метку с $\mathrm{N}$-конца и полиаргининовый мотив с C-конца. Данный рекомбинантный белок Sox2 использовали для получения поликлональных антител, специфичных к транскрипционному фактору Sox2. Результаты иммуноферментного анализа показали высокий уровень антителообразования при иммунизации рекомбинантным белком Sox2. Результаты иммуноблота показали, что полученные поликлональные антитела связываются с антигенной фракцией, молекулярная масса которой равна 35 кДа. Методом иммуноцитохимического анализа было определено, что поликлональные антитела имеют высокую специфичность связывания с нативным транскрипционным фактором Sox2 в эмбриональных и индуцированных плюрипотентных стволовых клетках. Полученные очищенные поликлональные антитела имеют высокую специфичность связывания с рекомбинантным антигеном Sох2, чем неочищенные поликлональные сыворотки. С помощью полученных антител нами была подтверждена их специфичность и избирательность на клеточных линиях ЭСК и ИПСК в качестве маркеров стволовых клеток. Таким образом, наши результаты показали, что полученные нами поликлональные антитела к Sox2 не уступают по специфичности и иммунохимическим характеристикам коммерческому аналогу и могут быть использованы для определения экспрессии данного транскрипционного фактора в плюрипотентных стволовых клетках.

Ключевые слова: Sox2, антиген, антитела, плюрипотентные стволовые клетки.

\section{Введение}

В настоящее время особый интерес представляют эмбриональные (ЭСК) и плюрипотентные стволовые клетки (ИПСК), наблюдение и контролирование фенотипических изменений дифференциации которых имеет жизненно важное значение для их использования в регенеративной медицине. Эти изменения включают в себя наличие или отсутствие экспрессии транскрипционных факторов и молекул клеточной поверхности, которые могут быть использованы в качестве маркеров. Обнаружение маркеров ЭСК и ИПСК с помощью коммерческих поликлональных антител (ПКА) является наиболее распространенным методом, который используется для подтверждения их статуса плюрипотентных предшественников.

Процессы клеточной и тканевой дифференцировки ЭСК и ИПСК отражаются в динамике экспрессии транскрипционных факторов и определенных маркерных белков. Транскрипционные факторы Oct-4, Nanog, Lin28, Sox2, Klf-4 и с-Mус, определяющие самоподдержание и плюрипотентность, экспрессируются на ранних стадиях эмбрионального развития и в плюрипотентных стволовых клетках [1-4]. Эти факторы, формирующие так называемую подсистему «внутренних регуляторов плюрипотентности» в ядрах плюрипотентных стволовых клеток, используются для демонстрации дифференцированного плюрипотентного статуса стволовых клеток [5].

Хотя существующие коммерческие антитела к транскрипционным факторам и молекулам клеточной поверхности являются ценными для исследования ЭСК, необходимы новые антитела для отслеживания изменений в процессе дифференцировки ЭСК и ИПСК [6]. Учитывая возрастающие исследования и эксперименты по использованию ИПСК клеток для регенеративной медицины и заместительной терапии, необходимо понимать природу процессов, происходящих в данном типе клеток. Одним из основных подходов является получение антител к созданным генно-инженерным методом рекомбинантным белкам, в особенности к транскрипционным факторам эмбриональных и плюрипотентных стволовых клеток.

Одним из транскрипционных факторов, участвующих в процессах пролиферации и самообновления недифференцированных эмбриональных и плюрипотентных стволовых клеток человека и животных, является Sox2. Ген Sox2 расположен в 3q26.3-q27 положении на длинном плече хромосомы. Sox2 ген кодирует 317 аминокислот белка и находится в интронной области Sox2OT (SOX2 overlapping transcript) 
гена с одним экзоном. Sox2 экспрессируется в ранних эмбриональных стволовых клетках бластоцисты, а затем в нейтральных стволовых клетках. Он является членом семейства белков SOX, которые несут ДНКсвязывающую высокоподвижную группу (HMG) домена и другие домены, регулирующие эмбриональное развитие и дифференцирование клеток в определенные линии. Sox2 играет важнейшую роль в поддержании эмбриональных и нейтральных стволовых клеток, тем самым открывает большие перспективы в исследованиях индуцирования плюрипотентности [7].

Также, Sox2 может служить в качестве специфического внутриклеточного маркера, позволяющего идентифицировать плюрипотентные стволовые клетки. Однако выделение этого белкового фактора, в частности, из ядер стволовых клеток в чистом виде для получения высокоспецифичных поликлональных антител является достаточно сложным. Лучшим решением этой сложной задачи является использование современных методов генной инженерии и молекулярной биологии для получения рекомбинантных белков в чистом виде и в достаточном количестве, которые можно использовать в качестве иммуногенов для получения антител. В связи с этим в Национальном центре биотехнологии была создана генно-инженерная конструкция (плазмидный вектор), несущая гены транскрипционного фактора Sox2, а также бактериальный штамм-продуцент этих белков [8]. Экспрессия гена Sox2 была подтверждена белковой масс-спектрометрией полных бактериальных лизатов, в результате которой были обнаружены пептиды, относящиеся с высокой достоверностью к пептидам человеческого белка Sox2. Одним из решений для получения высокоспецифичных антител к транскрипционному фактору Sox2, служащего в качестве маркера для определения стволовых клеток, является использование рекомбинантного белка Sox 2 в качестве антигена [8].

Таким образом, целью данного исследования было получение антител к рекомбинантному транскрипционному фактору Sox2 стволовых клеток человека и оценка их специфичности с помощью иммунологических методов для применения в фундаментальных и прикладных исследованиях плюрипотентных стволовых клеток человека.

\section{МАТЕРИАЛЫ И МЕТОДЫ}

Подготовка антигена. В работе использовали полученный методом плазмидной экспрессии, рекомбинантный антиген - специфический маркер Sox2, продуцируемый бактериальным штаммом Rosetta pLysS(DE3), несущим генетическую конструкцию pET-28a/Sox2. Для проведения иммунизации использовали антиген Sox2, очищенный металлохелатной хроматографией и диализированный в фосфатносолевом буфере (ФСБ) (рН 7,2-7,4).

Иммунизация животных. Для выполнения научной работы использовали лабораторных животных кроликов, весом 2,5-3,5 кг. Для иммунизации, антиген брали в концентрациях 300 и 150 мкг/мл в объеме 1 мл. В качестве контроля служили интактные животные того же возраста.

Получение поликлональных антител к рекомбинантному антигену Sox2. В первый день иммунизации антиген Sox2 в концентрации 300 мкг/мл, смешанного с ФСБ и полным адъювантом Фрейнда (Sigma, США), инъецировали кролику подкожно вдоль позвоночного столба. В следующих иммунизациях на 2-й неделе вводили антиген Sox2 в неполном адъюванте Фрейнда, на 4-й, 5-й и 6-й неделе в ФСБ в концентрации 150 мкг/мл. Через неделю после последней иммунизации отбирали кровь из ушной вены кролика для тестирования иммунологическими методами.

Очистка поликлональных антител. Из отобранной крови выделяли сыворотку центрифугированием в течение 10 мин. при 400 g. С помощью 76\% раствора сульфата аммония проводили осаждение сыворотки в течение ночи при $4^{\circ} \mathrm{C}$ на магнитной мешалке. Осажденный преципитат собирали и центрифугировали при 44920 g - 30 мин (Beckman, США). Удалив супернатант, осадок растворяли в 10 мл ФСБ (рН 7,2-7,4) и ставили на диализ против ФСБ на 24-48 ч., при $+4^{\circ} \mathrm{C}$ и постоянном перемешивании. Очищенные поликлональные антитела хранили при $+4^{\circ} \mathrm{C}$ консервированием $0,1 \%$ азидом натрия, и при $-20^{\circ} \mathrm{C}$ без консерванта, оставив необходимое количество для тестирования.

Определение концентрации антител. Концентрацию поликлональных антител определяли с помощью спектрофотометра Nanodrop (Thermo Scientific, США) при оптической плотности.

Иммуноферментный анализ. Иммуноферментный анализ проводился по следующей схеме: рекомбинантным антигеном Sox 2 в концентрации 0,01 мг/мл в ФСБ (рН 7,2-7,4), сенсибилизировали лунки планшета для иммунологических реакций (BD, США) и инкубировали в течение ночи при $+4^{\circ} \mathrm{C}$. Далее лунки планшета промывали три раза ФСБ с 0,005\%-ным содержанием твина-20 (ФСБ-Тв) и три раза ФСБ. Свободные участки носителя блокировали внесением 0,1 мл/лунку $1 \%$ раствора бычьего сывороточного альбумина (БСА) и проводили инкубацию планшета в течение 1 часа при $37^{\circ} \mathrm{C}$. Отмывка планшета осуществлялась как было описано выше. Затем сыворотки крови, отобранные в ходе и после последней иммунизации, вносили в лунки в разведении $1: 100$, и инкубировали 1 час при $37^{\circ} \mathrm{C}$. Лунки планшета промывали снова, вносили антитела против иммуноглобулинов кролика, меченых пероксидазой хрена конъюгат в разведении 1:5000 (Sigma, США) и инкубировали при $37^{\circ} \mathrm{C} 1$ час. После отмывки в лунки планшета добавляли по 0,1 мл субстрата фермента, перекиси водорода $\left(\mathrm{H}_{2} \mathrm{O}_{2}\right)$ и хромогена ортофенилендиамина (ОФД) (Sigma-Aldrich, США), раствор которого готовили непосредственно перед 
внесением по следующей схеме: 10 мг ОФД растворяли в 10 мл цитратно-фосфатного буфера (pH 4,5) и добавляли 0,1 мл 3\%-ной $\mathrm{H}_{2} \mathrm{O}_{2}$. Спустя 7-10 минут проявившуюся реакцию останавливали добавлением в ячейки 0,1 мл 2М серной кислоты. Результаты ИФА оценивали визуально и с помощью спектрофотометра (BioRad, CША) количественно при длине волны 492 нм. Окрашивание жидкости (раствором субстрата) в коричневый цвет различной интенсивности объясняло наличие положительной реакции.

Иммуноблот. Метод иммуноблотинга состоял из нескольких этапов: 1) проведение электрофореза; 2) перенос электрофореграммы на нитроцеллюлозную мембрану; 3) проявление нитроцеллюлозной реплики иммунохимической реакцией. Для проявления взаимодействия антигенов с антителами иммунохимической реакцией нитроцеллюлозную мембрану инкубировали 1 час при $37^{\circ} \mathrm{C}$ в растворе очищенных поликлональных антител, растворе 1\% БСА с ФСБ-Тв, в разведениях от 1:50, 1:100, 1:200, 1:400, 1:800 и 1:1600. В качестве контроля использовали коммерческие кроличьи антитела анти-Sох2 в количестве 1-3 мкг/мл (Invitrogen, США). Затем мембрану инкубировали в рабочем разведении антивидовых вторичных антител, меченных пероксидазой хрена, в разведении равном 1:500. Вновь отмывали и наблюдали проявление реакции после добавления раствора субстрата, содержащего 0,01 г 4-хлор-нафтола (Sigma, США), 0,1 мл 3\%-ной $\mathrm{H}_{2} \mathrm{O}_{2}$ и ФСБ.

Культивирование клеток. Индуцированные плюрипотентные стволовые клетки были получены репрограммированием соматических клеток - Т-лимфоцитов периферической крови человека (CytoTune iPS Reprogramming Kit, США). Клетки культивировали в соответствии с протоколом в полной питательной среде DMEM/F12 с добавлением 20\% заменителя сыворотки (Gibco, CША) и 4 мкг/мл основного фактора роста фибробластов (Invitrogen, США) [9]. ИПСК клетки культивировали на инактивированном фидерном слое мышиных эмбриональных фибробластов в течение 30-45 дней до 3 пассажа, после чего проводили иммуноцитохимический анализ.

Иммуноцитохимический анализ. Исследование поликлональных антител на уровень экспрессии в плюрипотентных стволовых клетках осуществляли иммунофлуоретическим методом. Клетки, пассированные за 1-2 дня до анализа, фиксировали 4\%-ным параформальдегидом в течение 20 минут и обрабатывали $0,1 \%$ раствором тритон X-100 в течение 5 минут, отмывали ФСБ. Затем клетки инкубировали в течение ночи при $4^{\circ} \mathrm{C}$ в растворе поликлональных антител в разведениях: 1:100, 1:500, 1:1000, 1:2000 и 1:4000. В качестве контроля использовали коммерческие кроличьи анти-Sox2 антитела в количестве 2-3 мкг/мл (Invitrogen, США). По окончанию инкубации образцы промывали, и инкубировали со вторичными Alexa-fluor 488 козлиными антикроличьими Ig G (H+L) антителами (Invitrogen, США) в разведении 1:500 в течение 1 часа при $37^{\circ} \mathrm{C}$, после чего вносили антивыгорающий реагент с флуоресцентным красителем DAPI (Invitrogen, США) для окрашивания ядер клеток. Анализ окрашенных образцов проводили с помощью флуоресцентного микроскопа (Axio Observer, Carl Zeiss) со встроенной CCD-камерой (Axiocam Erc5s, Carl Zeiss). Обработку полученных снимков проводили с помощью программы Image J.

\section{РЕЗУЛЬТАТЫ И ОБСУЖДЕНИЕ}

В данной работе с помощью иммунологических методов были получены кроличьи поликлональные антитела, специфичные к рекомбинантному антигену Sox2.

В исследовании использовались сыворотки иммунизированного животного и контрольные сыворотки, полученные до иммунизации животного. Для определения специфичности выделенных поликлональных сывороток крови иммунизированного животного и полученных ПКА проводили непрямой вариант ИФА, результаты которого отображены на рис. 1.

При измерении первичного иммунного ответа было обнаружено повышение продукции антител в поликлональной сыворотке, что свидетельствует о нормальной иммунной реакции организма в ответ на введение рекомбинантного Sox2.

При оценке вторичного иммунного ответа наблюдается подъем продукции антител, превышающий уровень первичного иммунного ответа почти в 2,5 раза и контрольный уровень почти в 5,5 раза.

Максимальный уровень антителообразования достигается через 40-50 дней после первой инъекции растворимого антигена Sox2. По окончании полного курса иммунизации уровень продукции антител в поликлональной сыворотке, очищенной диализом, был почти в 8 раз выше, в сравнении с вторичным иммунным ответом. Концентрация белка после диализа составила 10 мг/мл.

Таким образом, полученные очищенные поликлональные антитела имеют высокую специфичность связывания с рекомбинантным антигеном Sox2, чем неочищенные поликлональные сыворотки, что подтверждается сравнением продукции антител после первичного и вторичного иммунного ответа и после полного курса иммунизации в разведениях антител от 1:200 до 1:25600.

Для подтверждения антигенной специфичности антител в анализе иммуноблота поликлональные антитела, использованные в разведении от 1:50 до 1:1600 (рис. 2 А и Б), показали, что молекулярная масса антигенной фракции, взаимодействующей с ПКА, равна 35 кДа, что соответствует литературным данным [6]. Белки нарабатывались с высоким выходом, и видимой деградации на электрофореграмме не было замечено. Однако взаимодействие белков в иммуноблоте с ПКА выявило дополнительно несколько минорных полос, соответствующих белкам с меньшей молекулярной массой. Предположено, что 
определенная часть рекомбинантного белка в незначительной степени подвергается ограниченной протеолитической деградации. В связи с этим произошло связывание ПКА с данными минорными белками [10].

Таким образом, полученные кроличьи ПКА специфически реагируют с белковой фракцией антигена с молекулярной массой 35 кДа, имеющего высокие иммуногенные свойства. Следует отметить, что при высоком разведении 1:1600 реакция взаимодействия антител с антигеном аналогична реакции взаимодействия коммерческих антител с тем же антигеном (рис. 2 А и Б).

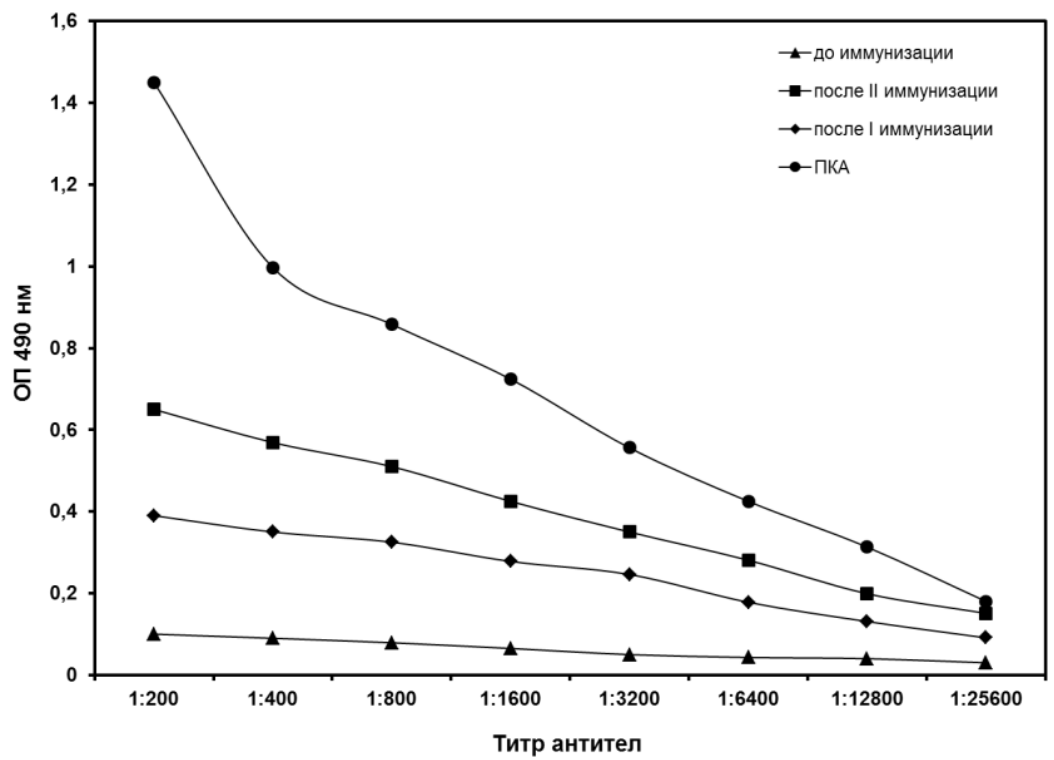

Рис. 1. Определение титра антител к Sox2 с помощью ИФА 


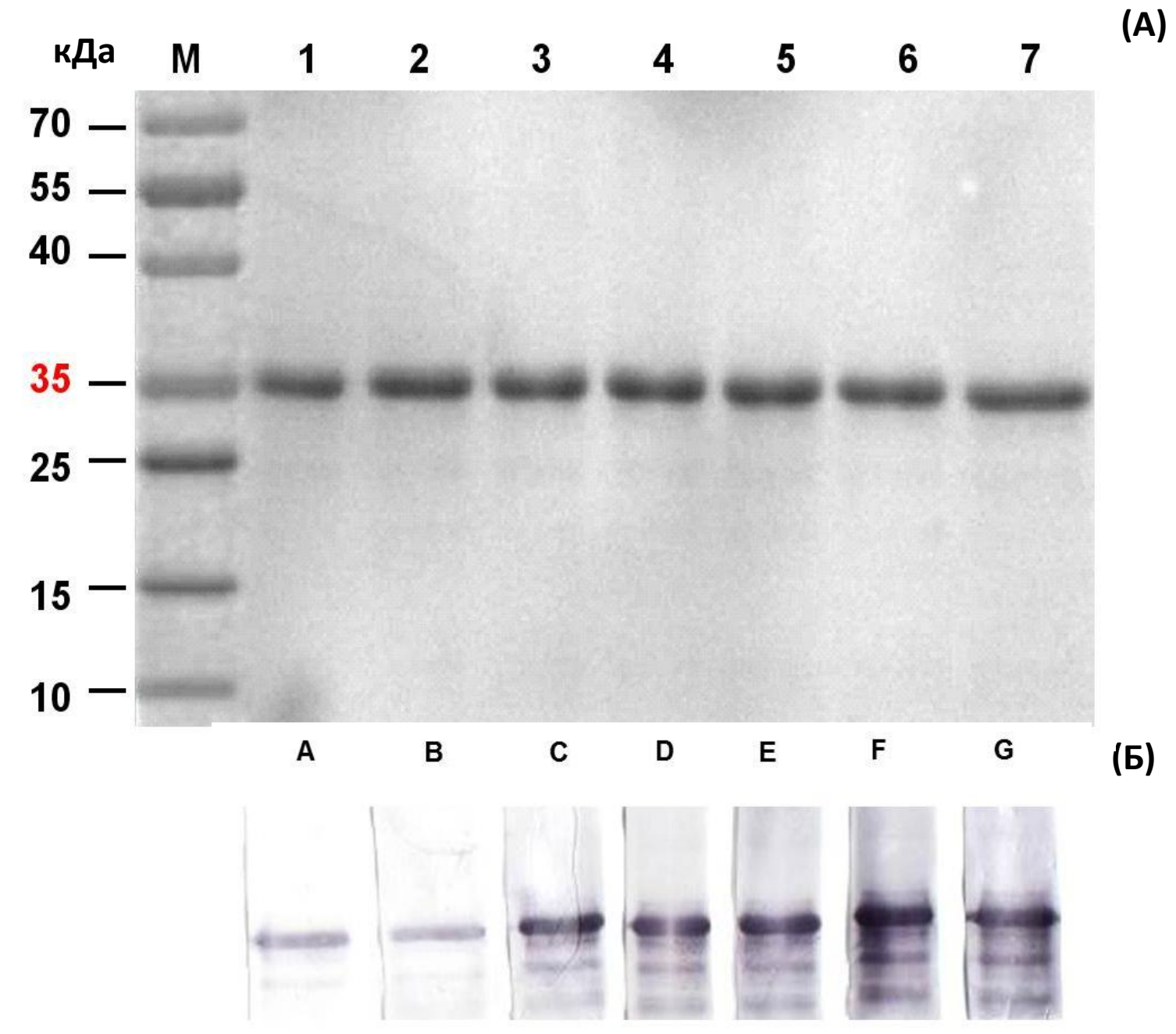

(A) - электрофорез очищенного рекомбинантного антигена Sox2; M - молекулярные маркеры; (Б) иммуноблот поликлональных антител к рекомбинантному антигену Sox2; A - коммерческие поликлональные кроличьи антитела к Sox2 (кат. №48-1400 Invitrogen, США) 3 мкг/мл; В - ПКА к Sox2 (1:1600); C - ПКА к Sox2 (1:800); D - ПКА к Sox2 (1:400); Е - ПКА к Sox2 (1:200); F - ПКА к Sox2 (1:100); $\mathrm{G}$ - ПКА к Sox2 (1:50).

Рис. 2. Иммуноблот поликлональных антител к рекомбинантному антигену Sox2 


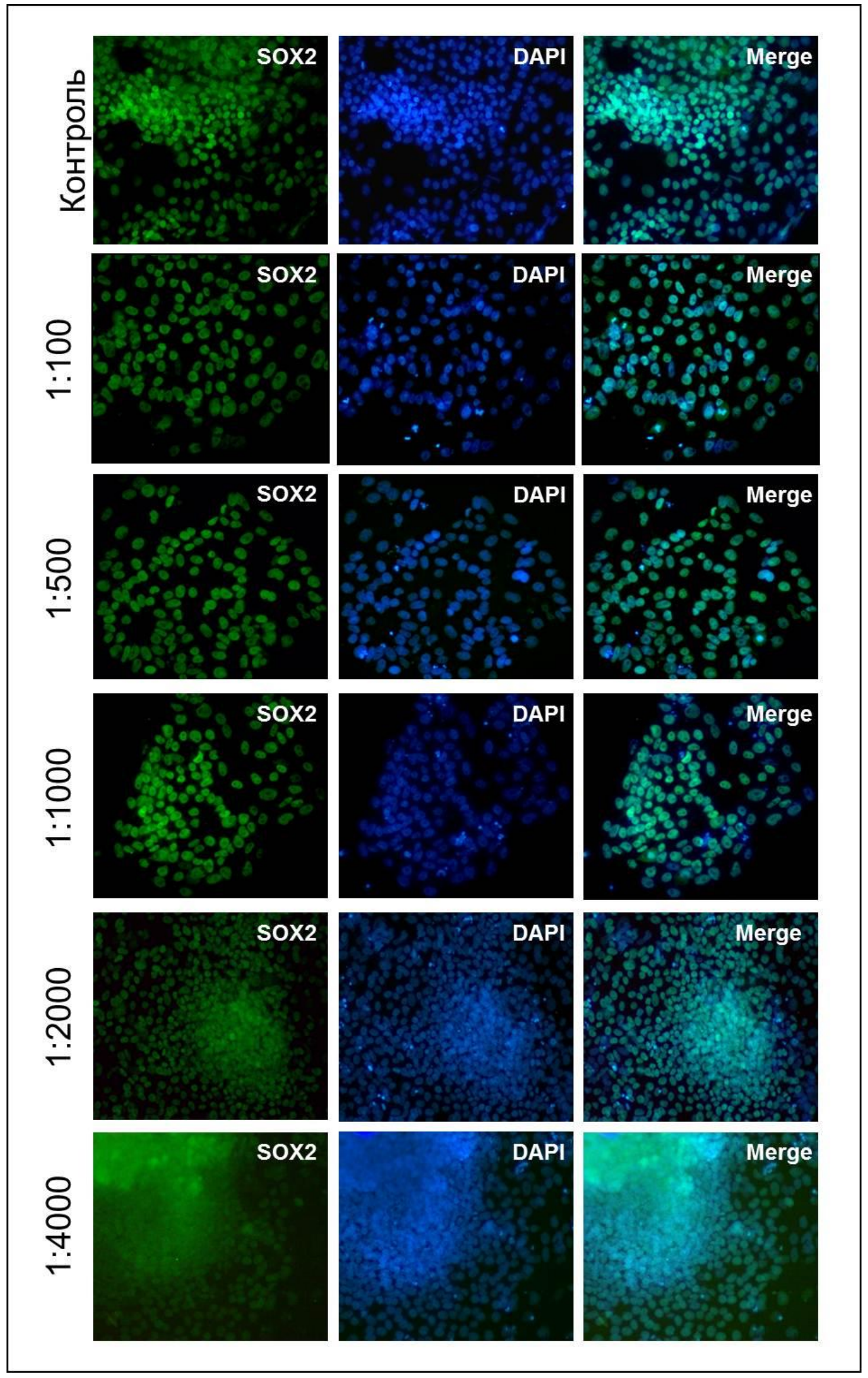

ИПСК окрашены поликлональными антителами к Sox2 зеленым цветом, ядра окрашены с DAPI синим цветом. Merge - совместное изображение двух снимков. (200х увеличение) 


\section{Рис. 3. Иммуноцитохимический анализ экспрессии транскрипционного фактора Sох2 в ИПСК.}

Поликлональные антитела к Sox2 после проверки в ИФА и в иммуноблоте тестировались для изучения экспрессии транскрипционного фактора Sox2 в ИПСК. Было отмечено, что высокий уровень экспрессии Sox2 наблюдается в недифференцированных ИПСК (рис. 3). Для того, чтобы определить свойства полученных антител в характеризации ИПСК, ПКА были проверены в следующих разведениях: 1:100, 1:500, 1:1000, 1:2000 и 1:4000. На рисунке 4 показаны ядра ИПСК, экспрессирующие белок Sох2, которые хорошо видны зеленым цветом. В свою очередь, коммерческие антитела были использованы в качестве контроля в разведении 1:100, согласно рекомендациям производителя.

В данной работе иммунофлуоресцентный анализ показал, что полученные антитела специфически реагируют с нативным транскрипционным фактором Sox2 в плюрипотентных стволовых клетках человека (рис. 3). Специфичность связывания поликлональных антител, начиная от разведения 1:100, была стабильной до 1:2000. Более слабая экспрессия наблюдалась в разведении антител 1:4000.

Полученные результаты на основе иммунологических методов доказывают, что полученные поликлональные антитела имеют высокую специфичность как с рекомбинантным антигеном Soх2, так и с нативным транскрипционным фактором Sox2 в плюрипотентных стволовых клетках человека. Таким образом, наши результаты показали, что специфичность и иммунохимические характеристики поликлональных антител не отличаются от коммерческого аналога.

Таким образом, на основании результатов исследований можно заключить, что является возможным использование полученных поликлональных антител к Sox2 в качестве специфического маркера для изучения функций транскрипционного фактора Sox2 и его роли в характеристике и идентификации плюрипотентного статуса стволовых клеток.

\section{Выводы}

1. В результате проведения исследований были получены поликлональные антитела, специфичные к рекомбинантному транскрипционному фактору Sox2.

2. Уровень антителообразования у иммунизируемого животного в течение первичного и вторичного иммунных ответов был примерно в два раза выше, чем у интактного животного.

3. Специфичность и иммунохимические характеристики полученных поликлональных антител позволяют использовать их для определения экспрессии транскрипционного фактора Sox2 в стволовых клетках.

\section{Литература}

1. Takahashi K., Yamanaka S. Induction of pluripotent stem cells from mouse embryonic and adult fibroblast cultures by defined factors // Cell. - 2006. - №126 (4). - P. 663-676.

2. Niwa H., Ogawa K., Shimosato .D, Adachi K. A parallel circuit of LIF signalling pathways maintains pluripotency of mouse ES cells // Nature. - 2009. - №460 (7251). - P. 118-22.

3. Masui S., Nakatake Y., Toyooka Y., Shimosato D., Yagi R, Takahashi K., Okochi H., Okuda A., Matoba R., Sharov A., Ko MS., Niwa H. Pluripotency governed by Sox2 via regulation of Oct3/4 expression in mouse embryonic stem cells // Nat. Cell Biol. - №9 (6): 625-635.

4. Chambers I., Tomlinson SR. The transcriptional foundation of pluripotency // Development. - 2009. №136 (14). - P. 2311-22.

5. Brazel C.Y., Limke T.L., Osborne J.K., Miura T., Cai J., Pevny L., Rao M.S. Sox2 expression defines a heterogeneous population of neurosphere-forming cells in the adult murine brain // Aging Cell. - 2005. - Aug. №4(4). - P. 197-207.

6. Cai J., Olson J.M., Rao M.S., Stanley M., Taylor E. and Ni H. Development of antibodies to human embryonic stem cell antigens // BMC Developmental Biology. - 2005. - P. 5-26.

7. Rizzino A. Sox 2 and Oct-3/4: a versatile pair of master regulators that orchestrate the self-renewal and pluripotency of embryonic stem cells // Wiley Interdiscip Rev SystBiol Med. -2009. - №1 (2). - P. $228-36$.

8. Балтабекова М.Ж., Абдуллаева В.Н., Хасенов Б.Б. Экспрессия генов человеческих белков SOX2 и NANOG в Esherichia coli // Материалы конференции «Генетика и биотехнология XXI века: проблемы, достижения, перспективы». - 2012. - С. 183.

9. Tomohisa Seki, Shinsuke Yuasa \& Keiichi Fukuda. Generation of induced pluripotent stem cells from a small amount of human peripheral blood using a combination of activated T cells and Sendai virus // Nature protocols. - 2012. - Vol.7, №4. - P. 718-28.

10. Lei Lei, Cui Xinxin, Zhang Shujin, Wang Huayan. Prokaryotic Expression of Mouse Sox2 Gene and Preparation of Its Polyclonal Antibody // Journal of Agricultural Biotechnology. - 2010. - Vol.18, №6. - P. 11631167. 


\section{Түйін}

Бағаналы жасушаларда экспрессияланатын Sox2 транскрипциялық факторы индукцияланған плюрипотенттік бағаналы жасушалар мен эмбрионалдық жасушалардың плюрипотенттілігіне көмектесеуде және жаңғыруында маңызды қызмет атқарады. Бұл зерттеуде, құрамында Sox2 рекомбинантты транскрипциялық факторын кодтайтын гені бар pET-28a/Sox2 құрылымы Rosetta pLysS (DE3) бактериялық штаммында эксспрессияланды. Рекомбинантты Sox2 ақуызы Sox2 транскрипциялық факторына телімді поликлоналды антидене алуға қолданылды. ИФА нәтижесі Sox2 рекомбинантты ақуызымен иммунизациядан кейін жоғары деңгейде антидене өндірісін қалыптастыратындығын көрсетті. Иммуноблот нәтижесі аталған антиген бөлімімен байланысқан поликлоналды антидене жалпы молекулалық массасы 35 $\mathrm{kDa}$ болатындығын көрсетті. Иммуноцитохимиялық әдіс арқылы зерттеулер нәтижесі поликлоналды антиденелер эмбрионалды жасушаларда және индукцияланған плюрипотенттік бағаналы жасушаларда нативті Sox2 транскрипциялық факторына жоғары телімділігін көрсетті. Қол жеткізілген поликлоналды антиденелер бағаналы жасушаларда Sox2 транскрипциялық факторын эксспрессиясын тұрақтандыруда қолданылуы мүмкін.

Кілтті сөздер: Sox2, антиген, антидене, плюрипотенттік бағаналы жасушалар.

\section{Summary}

Sox 2 transcription factor, which is expressed in the embryonic stem cells, plays an important role in selfrenewal and maintaining pluripotency of embryonic and induced pluripotent stem cells. In this study, by the method of plasmid expression of bacterial strain Rosetta pLysS (DE3), which carrying the genetic construction pET28a/Sox2, was obtained Sox 2 recombinant transcription factor. Sox 2 target gene was inserted under the control of the T7 RNA polymerase promoter and contained a histidine tag at the N-end and polyarginine motif with the Cterminus. This Sox 2 recombinant protein was used for the development of polyclonal antibodies which specific to the Sox 2 transcription factor. Enzyme-linked immunosorbent assay's results showed a high level of the antibodyproducing after immunization with the Sox 2 recombinant protein. Immunoblot results indicated that the developed polyclonal antibodies bind to the antigen fraction with molecular weight of $35 \mathrm{kDa}$. By immunocytochemical method of analysis, it was determined that the polyclonal antibodies have highly specificity of binding to native Sox 2 transcription factor in embryonic and induced pluripotent stem cells. The developed purified polyclonal antibodies have highly specificity of binding to the recombinant antigen Sox2, than unpurified polyclonal sera. Using these antibodies, we have confirmed the specificity and selectivity of these antibodies on several ESC and IPSC lines as stem cells markers. Thus, our results showed that our developed polyclonal antibodies to Sox 2 are highly competitive in specificity and immunochemical characteristics with commercial counterparts and can be used to determine the expression of this transcription factor in pluripotent stem cells.

Keywords: Sox2, antigen, antibody, pluripotent stem cells. 